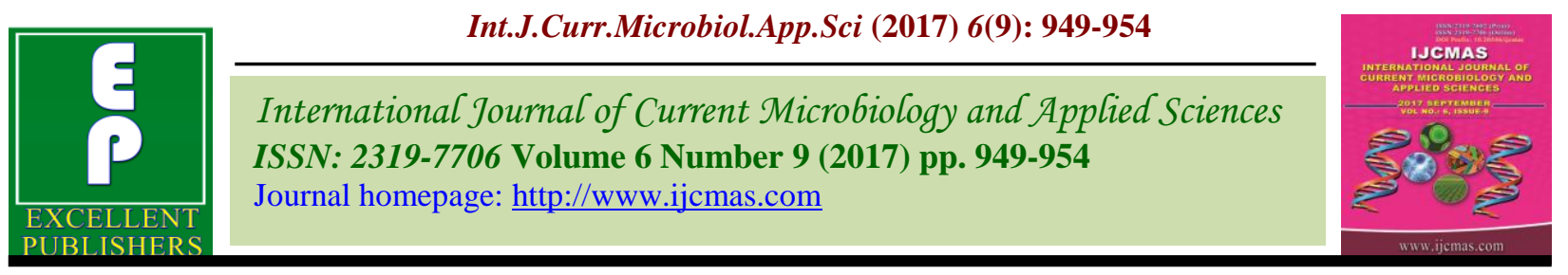

Original Research Article

https://doi.org/10.20546/ijcmas.2017.609.114

\title{
In vitro Efficacy of Fungicides against Alternaria tenuissima Causing Leaf Blight of Kodo Millet
}

\author{
K. Hariprasad, A. Nagaraja, Suresh Patil" and Gururaj Hawaldar \\ Department of Plant Pathology, UAS, GKVK, Bengaluru - 65, Karnataka, India \\ *Corresponding author
}

A B S T R A C T

\begin{tabular}{|l|}
\hline Ke y w o r d s \\
Alternaria \\
tenuissima, \\
Fungicides, in vitro. \\
\hline Article Info \\
\hline Accepted: \\
17 July 2017 \\
Available Online: \\
10 September 2017 \\
\hline
\end{tabular}

In vitro screening of different contact, systemic and combi-products against Alternaria tenuissima the fungus causing leaf blight of kodo millet was done employing poison food technique. The results revealed that, among the four contact fungicides, mancozeb at 0.15 and 0.20 per cent concentration gave the maximum inhibition (69.33 and 66.67\%) of mycelial growth. Among the five different combi-products studied, maximum inhibition of mycelial growth of 87.03, 86.66 and 85.18 per cent was noticed in hexaconazole + zineb at $0.10,0.15$ and 0.20 per cent concentrations, but among the five different systemic fungicides azoxystrobin recorded the maximum inhibition of $100,98.88,98.88$ per cent at the three concentrations of $0.05,0.075,0.10$ per cent respectively.

\section{Introduction}

Millets are one of the oldest foods known to humans and possibly the first cereal grains to be used for domestic purposes.

Millets are small seeded grasses that are hardy and suitable for dry zones as rain-fed crops, under marginal conditions of soil fertility and crop management.

Millets are also unique due to their short growing season. Among the small millets kodo millet (Paspalum scrobiculatum L.) is one of the hardiest millets. India and West Africa are the major growers of kodo millet and India is considered as the centre of origin of this crop (Yadava, 1997).
Although the crop is hardy, it is challenged by many fungal diseases and leaf blight caused by Alternaria tenuissima (Fr.) Keissl is one of the most destructive diseases, which if occurs at early stages of crop growth can reduce the yield drastically.

Though the cultivation of resistant varieties is the cheapest way of disease management, in the absence of good high yielding resistant varieties, use of fungicides to control the disease is an integral practice. Therefore, investigations were undertaken to know which fungicides are effective in vitro so as to advocate their usage to manage Alternaria tenuissima that causes leaf blight disease. 


\section{Materials and Methods}

The efficacy of four contact, five each of systemic and combi fungicides were evaluated against $A$. tenuissima at different concentrations using Potato dextrose agar medium employing poisoned food technique (Nene and Thapliyal, 1982).

Potato dextrose agar was prepared and autoclaved. The medium was cooled to $50^{\circ} \mathrm{C}$. Fungicides were dissolved in sterilized water to make the stock solution. Appropriate quantity of stock solution was added to PDA, to get the desired concentration of the fungicide; the flasks were agitated gently to aid in uniform dispersion of the fungicide into the medium.

About 15 to $20 \mathrm{ml}$ of poisoned PDA was poured into $90 \mathrm{~mm}$ Petri plates and allowed to solidify. One $7 \mathrm{~mm}$ disc of the actively growing culture of twelve days old $A$. tenuissima was transferred aseptically to the centre of each Petri plates containing the poisoned medium. Control was maintained with the pathogen under similar conditions on PDA without poisoning. Inoculated plates were incubated at $27 \pm 1^{\circ} \mathrm{C}$ for 10 days and the colony diameter was recorded by measuring the radial growth of the fungus in two directions at right angle to each other and the average diameter was calculated.

The per cent inhibition of the growth over control was determined (Vincent, 1947).

$I=\frac{C-T}{C} \times 100$

Where,

$\mathrm{I}=$ Per cent inhibition of the mycelium

$\mathrm{C}=$ Growth of the mycelium in control

$\mathrm{T}=$ Growth of the mycelium in treatment

\section{Results and Discussion}

\section{In vitro efficacy of contact fungicides}

The efficacy of four contact fungicides tested against $A$. tenuissima at three concentrations i.e., $0.10,0.15$ and 0.20 per cent by poisoned food technique revealed that, while Mancozeb $(66.74 \%)$ gave the maximum inhibition of mycelial growth but, Chlorothalonil (46.96 $\%$ ) had the least inhibition (Table 1a and Plate 1). Significant difference was observed for different concentrations; while 0.20 per cent recorded maximum inhibition of mycelial growth $(62.44 \%)$ least was at 0.15 per cent $(49.55 \%)$ that was on par with $0.10 \%$. With regard to interaction effects of fungicides and concentrations, maximum mycelial inhibition was recorded in mancozeb at $0.15(69.33 \%)$, $0.20(66.67 \%)$ and 0.10 per cent $(64.22 \%)$ that was on par with copper oxy chloride and captan both at 0.2 per cent (65.11 and $65.78 \%$ respectively).

Similarly, Ganie et al., (2013) reported that mancozeb irrespective of concentration completely inhibited the growth of $A$. solani. Likewise Thaware et al., (2010) said that mancozeb 0.2 per cent completely inhibited the growth of the test fungus A. alternata. Mishra and Gupta (2012) observed that the mycelial growth of $A$. porri was completely inhibited by mancozeb at 0.2 per cent. Mancozeb inactivates the sulphaydryl groups of amino acids and enzymes of fungal cell, resulting in disruption of lipid metabolism, respiration and production of adenosine triphosphate.

\section{In vitro efficacy of combi fungicides}

Of the five different combi-fungicides evaluated at three different concentrations viz., $0.10,0.15$ and 0.20 per cent for their efficacy against $A$. tenuissima by poisoned food technique; maximum inhibition of 
mycelial growth was noticed in Hexaconazole+ Zineb (86.29\%) that was comparable to Tebuconazole + Trifloxystrobin $(84.44 \%)$ and the minimum inhibition was noticed in case of carbendizim + mancozeb (76.41\%) (Table 1b and Plate 1). With respect to different concentrations, 0.15 and 0.20 per cent recorded the highest inhibition of 80.44 and 81.77 per cent respectively. Among the interaction effects, Hexaconazole + Zineb at all the three concentrations showed maximum mycelial inhibition $(87.03,86.66$, and $85.18 \%$ ) which was on par with Tebuconazole + Trifloxystrobin both at $0.20,0.15$ per cent ( 85.55 and $87.40 \%$ respectively).
Roopa et al., (2014) reported that combi fungicide hexaconazole 4 per cent + zineb 68 per cent @0.2per cent recorded 88.88per cent inhibition in the mycelial growth of $A$. solani. Avtar is a combi product containing zineb which is a broad-spectrum fungicide with protective action. It is fungi toxic when exposed to air and is converted to an isothiocyanate, which inactivates the sulphaydryl ( $\mathrm{SH})$ groups in enzymes of fungi. It acts by blocking the metabolism of pathogenic fungus at cellular level. Whereas hexaconazole which is a highly systemic triazole fungicide, acting as protective, curative and eradicant with strong antisporulant and translaminar action. It is a potent "Ergosterol biosynthesis inhibitor".

Table.1a In vitro efficacy of contact fungicides on A. tenuissima

\begin{tabular}{|l|r|r|r|r|}
\hline \multirow{2}{*}{ Fungicides / Concentration } & \multicolumn{2}{|c|}{ Per cent inhibition of mycelial growth } & \multirow{2}{*}{ Mean } \\
\cline { 2 - 4 } & \multicolumn{1}{c|}{$\mathbf{0 . 1 0 \%}$} & \multicolumn{1}{c|}{$\mathbf{0 . 1 5 \%}$} & \multicolumn{1}{c|}{$\mathbf{0 . 2 0 \%}$} & \\
\hline $\begin{array}{l}\text { Mancozeb 75 \% WP (Dithane } \\
\text { M45) }\end{array}$ & $64.22(53.27)$ & $69.33(56.38)$ & $66.67(54.74)$ & 66.74 \\
\hline $\begin{array}{l}\text { Chlorothalonil 75 \% WP } \\
\text { (Kavach) }\end{array}$ & $56.67(48.89)$ & $32.00(34.34)$ & $52.22(46.28)$ & 46.96 \\
\hline $\begin{array}{l}\text { Copper oxy chloride 50 \% WP } \\
\text { (Blitox) }\end{array}$ & $36.00(36.85)$ & $41.11(39.85)$ & $65.11(53.80)$ & 47.40 \\
\hline Captan 50 \% WP (Captaf) & $53.56(47.06)$ & $55.78(48.39)$ & $65.78(54.26)$ & 58.37 \\
\hline Mean & $\mathbf{5 2 . 6 1}$ & $\mathbf{4 9 . 5 5}$ & $\mathbf{6 2 . 4 4}$ & 54.86 \\
\hline & Fungicide (F) & Concentration (C) & F×C \\
\hline S.Em \pm & 0.82 & & 0.95 & 1.65 \\
\hline CD (P 0.01) & 3.13 & & 3.61 & 6.26 \\
\hline
\end{tabular}

Note: Figures in the parenthesis are arc sine transformed values. 
Table.1b In vitro efficacy of combi fungicides on A. tenuissima

\begin{tabular}{|c|c|c|c|c|}
\hline \multirow{2}{*}{ Combi-fungicides / Concentration } & \multicolumn{3}{|c|}{ Per cent inhibition of mycelial growth } & \multirow{2}{*}{ Mean } \\
\hline & $0.10 \%$ & $0.15 \%$ & $0.20 \%$ & \\
\hline $\begin{array}{l}\text { Hexaconazole+ Zineb } 4 \%+68 \% \\
\text { WP (Avtar) }\end{array}$ & $85.18(67.36)$ & $86.66(68.59)$ & $87.03(68.92)$ & 86.29 \\
\hline $\begin{array}{l}\text { Fenamidone+Mancozeb } 50 \%+25 \\
\% \text { WG (Sectin) }\end{array}$ & $78.88(62.68)$ & $80.37(63.82)$ & $81.48(64.63)$ & 80.24 \\
\hline $\begin{array}{l}\text { Carbendazim+Mancozeb 12\% + } \\
63 \% \text { WP (Saaf) }\end{array}$ & $76.66(61.12)$ & $74.44(59.65)$ & $78.14(62.13)$ & 76.41 \\
\hline $\begin{array}{l}\text { Tebuconazole + Trifloxystrobin } 50 \\
\%+25 \% \text { WG (Nativo) }\end{array}$ & $80.37(63.71)$ & $87.40(69.24)$ & $85.55(67.67)$ & 84.44 \\
\hline $\begin{array}{l}\text { Carboxin + Thiram } 37.5 \%+37.5 \% \\
\text { WS (Vitavax power) }\end{array}$ & 68.51(55.87) & $73.33(58.92)$ & $76.66(61.11)$ & 78.83 \\
\hline \multirow{2}{*}{\multicolumn{2}{|c|}{\begin{tabular}{r|}
77.92 \\
Fungicide $(\mathbf{F})$
\end{tabular}}} & 80.44 & 81.77 & 80.04 \\
\hline & & \multicolumn{2}{|c|}{ Concentration $(\mathbf{C})$} & $\mathbf{F} \times \mathbf{C}$ \\
\hline S.Em \pm & 0.60 & & 0.46 & 1.04 \\
\hline CD (P 0.01) & 2.33 & & 1.80 & 4.03 \\
\hline
\end{tabular}

Note: Figures in the parenthesis are arc sine transformed values

Table.1c In vitro efficacy of systemic fungicides on A. tenuissima

\begin{tabular}{|c|c|c|c|c|}
\hline \multirow{2}{*}{ Fungicides / Concentration } & \multicolumn{3}{|c|}{ Per cent inhibition of mycelial growth } & \multirow{2}{*}{ Mean } \\
\hline & $0.05 \%$ & $0.075 \%$ & $0.10 \%$ & \\
\hline $\begin{array}{l}\text { Carbendazim } 50 \% \text { WP } \\
\text { (Bavistin) }\end{array}$ & $98.14(82.17)$ & $98.51(83.00)$ & $99.25(85.06)$ & 98.64 \\
\hline $\begin{array}{l}\text { Tebuconazole } 25 \% \text { EC } \\
\text { (Folicur) }\end{array}$ & $86.29(68.27)$ & $87.40(69.21)$ & $88.14(69.86)$ & 87.28 \\
\hline Propiconazole $25 \%$ EC (Tilt) & $75.55(60.36)$ & $81.11(64.23)$ & $86.66(68.58)$ & 81.11 \\
\hline $\begin{array}{l}\text { Hexaconazole } 5 \% \text { EC } \\
\text { (Contaf) }\end{array}$ & $84.81(67.06)$ & $86.66(68.58)$ & $87.77(69.53)$ & 86.41 \\
\hline $\begin{array}{l}\text { Azoxystrobin } 23 \% \text { EC } \\
\text { (Amistar) }\end{array}$ & $98.88(83.94)$ & $98.88(83.94)$ & $100.00(90.00)$ & 99.25 \\
\hline Mean & 88.74 & 90.51 & 92.37 & 90.54 \\
\hline & Fungicide (F) & \multicolumn{2}{|c|}{ Concentration $(\mathrm{C})$} & $\mathbf{F} \times \mathbf{C}$ \\
\hline S. Em \pm & 0.71 & \multicolumn{2}{|c|}{0.55} & 1.23 \\
\hline CD (P 0.01) & 2.76 & \multicolumn{2}{|c|}{2.14} & 4.79 \\
\hline
\end{tabular}

Note: Figures in the parenthesis are arc sine transformed values. 
Plate.1 In vitro efficacy of fungicides on A. tenuissima

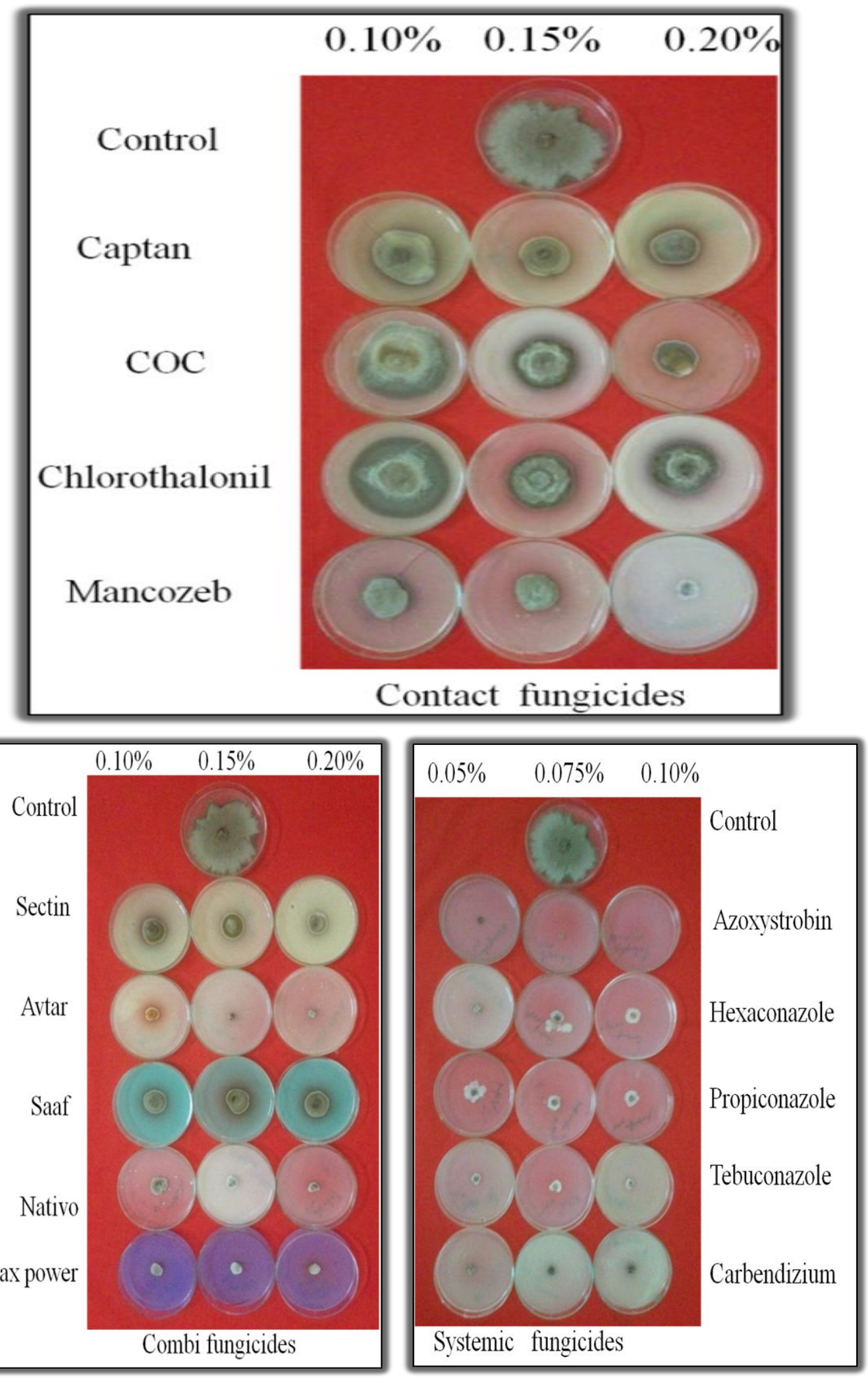


In vitro efficacy of systemic fungicides

Among the five systemic fungicides Azoxystrobin (99.25\%), recorded the maximum inhibition of mycelial growth which was on par with Carbendazim (98.64\%).But the minimum mycelial inhibition was observed in Propiconazole (81.11\%) (Table 1c and Plate 1). Treatment with different concentrations showed highest mycelial inhibition at 0.10 per cent $(92.37 \%)$ which was on par with $0.075 \%$ (90.51\%) with lowest inhibition at 0.05 per cent $(88.74 \%)$. Of the interactions, though Azoxystrobinat $(0.10 \%)$ recorded 100 per cent inhibition it was comparable to 0.05 and 0.075 per cent (98.88\% each) of the same compound as also Carbendazimat all the three concentrations (98.14, 98.51, and $99.25 \%$ respectively).

Mishra and Gupta (2012) reported that, in the in vitro evaluation of fungicides, azoxystrobin $(0.1 \%)$ completely inhibited Stemphylium vesicarium. Horsfield et al., (2010) reported that azoxystrobin and difenconazole were highly effective in controlling the early blight disease. Azoxystrobin binds very tightly to the Qo site of Complex III of the mitochondrial electron transport chain, thereby ultimately preventing the generation of ATP. However, carbendazim being a benzimidazole the fungicide interferes with energy production and cell wall synthesis of fungi (Nene and Thapliyal, 1982); and induced nuclear instability by disturbing the mitosis and meiosis (Davidse, 1986).

\section{References}

Davidse, L. C., 1986, Benzimidazole, fungicides mechanism of action and biological impact. Аnnu. Rev. Phytopathol., 24: 43-65.

Ganie, S. A., Ghani, M. Y., Anjum, Q., Nissar, Q., Shabir, U. R. and Dar, W. A., 2013, Integrated management of early blight of potato under Kashmir valley conditions. Afr. J. Agric. Res., 8 (41): 5104-5115.

Horsfield, A. A., Wicks, B. D., Davies, C., Wilson, A. D. and Paton, A. S., 2010, Effect of fungicide use strategies on the control of early blight Alternaria solani and potato yield. Aust. Pl. Pathol, 39: 368-375.

Mishra, R. K., and Gupta, R. P., 2012, In vitro evaluation of plant extracts, bio-agents and fungicides against Purple blotch and Stemphylium blight of onion. J. Med. Plant Res., 6(4): 5840-5843.

Nene, Y. L., and Thapliyal, P. N., 1982, Fungicides in Plant Diseases Control (Ed) : Oxford and IBH publishing Co. Pvt. Ltd., New Delhi, pp. 325.

Roopa, R. S., Yadahalli, K. B. and Shree, K., 2014, Evaluation of natural plant extracts, antagonists and fungicides against early blight caused by $A$. solani in vitro. Bioscan, 9 (3): 1309-1312.

Thaware, D. S., Fugro, P. A., Jadhav, Y. T., Magar, S. V. and Karande, R. A., 2010, In vitro evaluation of different fungicides, plant extracts and bio-agents against Alternaria alternata (Fr.) Keissler causing leaf blight of cowpea. Int. J. Plant. Prot., 3 (2): 356-360.

Vincent, J. M., 1947, Distribution of fungal hyphae in the presence of certain inhibitors. Nature, 159: 850.

Yadava, H. S., 1997, Retrospect and prospect of kodo millet in Indian agriculture. Proc. Nat. Seminar on Small millets, Coimbatore, India p.7-9.

\section{How to cite this article:}

Hariprasad, K., A. Nagaraja, Suresh Patil and Gururaj Hawaldar. 2017. In vitro Efficacy of Fungicides against Alternaria tenuissima Causing Leaf Blight of Kodo Millet. Int.J.Curr.Microbiol.App.Sci. 6(9): 949-954. doi: https://doi.org/10.20546/ijcmas.2017.609.114 